\title{
Study on Socio Economic Aspects of the Farmers under Lift Irrigation Schemes on Nallamada Drain in Krishna Western Delta
}

\author{
A. Rama Rao ${ }^{1 *}$ and M. Raghu Babu ${ }^{2}$ \\ ${ }^{1}$ Krishi Vigyan Kendra, Kondempudi, Visakhapatnam, India \\ ${ }^{2}$ Acharya N.G. Ranga Agricultural University, India \\ *Corresponding author
}

\section{A B S T R A C T}

\begin{tabular}{|c|}
\hline Keywords \\
\hline $\begin{array}{l}\text { Nallamada drain, } \\
\text { Lift irrigation, Crop } \\
\text { yield and returns }\end{array}$ \\
\hline Article Info \\
\hline $\begin{array}{l}\text { Accepted: } \\
15 \text { September } 2018 \\
\text { Available Online: } \\
10 \text { October } 2018\end{array}$ \\
\hline
\end{tabular}

It was found that on average a total quantity of water flow in Nallamada command in a year was $43.84 \mathrm{TMC}$, in addition to the $6 \mathrm{TMC}$ of water being used for all the Lift Irrigation Schemes above the gauging station for all the crops under Nallamada command in Krishna Western Delta. During socio- economic survey of beneficiary and nonbeneficiary farmers in the five randomly selected villages under Nagulapadu Lift Irrigation Scheme, effort were made to analyse the socio- economic and gender impact of Lift Irrigation Scheme on the lives of deprived farmers. Farmers were responded that they were aware of the fact that they were assured of water supply for irrigation that helped in enhancing the crop yields. They were convinced that their income levels increased due to yield improvement. Women farmers were of the opinion that they had been leading better quality life after introduction of Lift Irrigation Scheme. They opined that with the increased income levels, they had much better opportunity to provide medical and education facilities for their children.

\section{Introduction}

In the way of effective utilization and management of water flow quantities Lift Irrigation Schemes to be established to provide water to the fields at higher level. In this process, the distribution part is very important Water can be lifted from wells, rivers, irrigation tanks etc. and conveyed through pipes made of cement, steel, PVC etc. There are about 353000 and 19500 Lift Irrigation Schemes established in India and Andhra Pradesh respectively. In Krishna Western Delta Nallamada drain is located upstream end at Vogeru near Chilakulurupet
$60.5 \mathrm{~km}$ distance to the downstream end at zero face of the Bapatla jurisdiction close to sea mouth. There are 64 LIS established on Nallamada drain, of which one scheme covers maximum extent of 3200 ha and minimum of 15.6 ha the commercial crops are cultivated mostly Cotton, Chilly, Maize, Tobacco and Bengal gram.

Ahmed and Krishnan (1998) in their study "A conceptual overview on the impact of irrigation on gender roles in Indian agriculture" presented outlining three reasons for the gender blindness of irrigation policies the limited notion of equity in irrigation 
systems; The improper division between water for productive and domestic purposes; and the male bias of professional knowledge systems such as the irrigation bureaucracy.

Kolavalli et al., (1993) in their study on ground water utilization in East Utter Pradesh revealed that the capital cost on tube well ranged from Rs. 15,000 to Rs 21,000/-. The cost of irrigation for tube well owners was considerably higher as compared with public irrigation system. The average cost per hectare ranged from about Rs. 950/- to Rs. 2,200/-. Studying the impact of subsidies on ground water investment, it was identified that impacts of subsidies were the most effective in influencing ground water investment. IRR was estimated at different levels of subsidy.

NABARD (1995) investigated the technical, financial and organizational problems that have been encountered in implementing Lift Irrigation Schemes in Maharashtra state, India, and assessed the economic impact of Lift Irrigation Schemes. A total of seven schemes (Five from Krishna basin and one each from Godavari and Tapi basins) were selected. The agricultural year 1992-93 was taken as the reference year of the study. Implementation of the Lift Irrigation Schemes was beset with many operational problems. In the process of designing the Lift Irrigation Schemes, the water distribution system was practically lost sight of which resulted in reduced coverage of irrigable area and wasteful use of scarce irrigation water.

Inamdar et al., (1996) studied investment costs, operating costs and returns of Lift Irrigation and bi wall drip irrigation. Data were collected from 98 commercial crops growing farmers in the command area of the Lift Irrigation Scheme in Ankalkop village, Sangli District, Maharashtra, India, both before 1987-88 and after 1989 - 90 installation of the biwall drip irrigation unit. The benefit cost ratio of biwall drip irrigation was found to be 1.43 in the command area.

\section{Materials and Methods}

The details of background information pertaining to socio-economic, gender issues about the beneficiary farmers and nonbeneficiary farmers of the study area, sampling procedure, nature and source of data, selection of respondents (sample farmers), the analytical tools and techniques employed and some related definitions are presented in the section. Primary and secondary data collected in order to fulfil the objective.

\section{Primary and Secondary data}

For meeting the requirement of the specific objective of the study, necessary information was elicited from the sample farmers through personal interview method with the help of pre-tested and structured schedule format. Data were collected on aspects such as the total number of irrigations per season, crops grown, cropping pattern, land use pattern etc. Opinion survey method was adopted to know the operational problems and constraints faced by the farmers in getting benefits from lift irrigation scheme (Table 7).

Secondary data on land use pattern, crops and cropping pattern, agro-climatic features of the study region (area), cost of lift irrigation scheme, maintenance and repair performance etc. were obtained from the Nagulapadu Lift Irrigation Scheme operating committee, Pedanandipadu.

\section{Tabular analysis}

Tabular approach was followed for analyzing the general characteristics of the sample farmers, their resource utilization, and labour utilization, price of inputs, returns and profits 
per hectare for comparison. The data was compared and contrasted with the aid of simple statistical measurable averages and percentages to achieve meaningful presentation of results.

\section{Results and Discussion}

In any scientific investigation, the necessity of basic information is indispensable since, it provides deeper insights into the basic aspects of the study area and also provides the impact of interventions on the socio - economic aspects of social community. The general characteristics of the respondents in the study area were presented in Table 1.

\section{Age}

The average age of farmers acts as an important variable in decision-making ability of the respondents. Nearly 33.33 per cent of the farmers were young, while 50 per cent were middle aged and about 17 per cent were old aged under the Lift Irrigation Scheme, while it was $26.66,53.33$ and 20 percent for young, middle and old aged in non-beneficiary category of respondents.

\section{Education level}

The education level of farmers was categorized into five groups. The percentage of illiterates was about 23.33 and 33.33 percent in the beneficiary and non-beneficiary categories, respectively. Majority of respondents up to primary level education were found in both categories, indicated that educationally the study area was backward. Majority of respondents studied only up to primary level in both the category of farmers. This reflects upon poor adoption capacity of the farmers and general backwardness of the region. The percentage of highly educated farmers was negligible.

\section{Occupation}

The occupation of the farmers was studied classifying into two main categories as agriculture and agriculture plus others (other enterprises, service and business). Among the beneficiaries 70 per cent of respondents had Agriculture as their main occupation, 30 per cent of respondents had Agriculture plus others. In the case of non-beneficiary the percentage of farmers purely dependent on agriculture $(56.66 \%)$ was less than that of beneficiary group $(70 \%)$.

\section{Family size}

Middle size families comprising 5-8 members were predominant in the study area. It was inferred from the results that majority of the respondents in the study area were agriculture based. The percentage of farmers taking up agriculture was more under the command than outside the command. This was possible because of provision of irrigation facility. The farmers outside the command tried to make up the family income by Non-agricultural Enterprises like petty business etc. Most of the farm families in the study area belonged to middle size category. Small size families were more in beneficiary category (about 67\%) than Non-beneficiary's category $(60 \%)$.

\section{Land holding}

In both beneficiary and non-beneficiary category, the small farmers dominated in numbers. 60-67 per cent of farmers in both the categories were small. Medium farmers were the next important component in both the categories.

While beneficiary category had about 20 percent medium farmers, non-beneficiary had 26.66 per cent of them. It was a welcome sign that scheme has benefitted mostly the small farmers in the region. 
Pattern of land utilization by the respondents

Among the beneficiary farmers 66.66 per cent were small, followed by medium $20 \%$ and large $(13.33 \%)$. Beneficiary farmers were blessed with 100 per cent irrigation on their farms. The average land holding of beneficiary and non-beneficiary farmers was slightly more than that of beneficiaries' at 3.36 acre. Here, also size distribution of sample beneficiaries was same as that of beneficiaries. But the non-beneficiary farmers lacked irrigation facility (Table 2).

\section{Assets position of the respondents}

The asset position of the sample respondents was presented in Table 3 significant difference was noticed in the value of assets in beneficiary and non- beneficiary categories of farmers. While the total value of asset in the beneficiary category was Rs.2, 35,125, it was Rs. 2, 35,988 in the latter category. Among both the total assets of beneficiary and nonbeneficiary farmer's tractor contributed to nearly half of the total value of assets.

The second important item of assets was dwelling house, contributing to about 30 per cent of the total assets in the beneficiary category and about 25 per cent in the nonbeneficiary category.

Motorcycle was another important asset of both categories of farmers, contributing to about 9 per cent of total value of assets. Remaining were all farm implements etc.

Table.1 General characteristics of the sample farmers

\begin{tabular}{|l|c|c|c|c|}
\hline \multicolumn{1}{|c|}{ Categories } & \multicolumn{2}{|c|}{$\begin{array}{c}\text { Beneficiaries of lift } \\
\text { irrigation }\end{array}$} & \multicolumn{2}{c|}{$\begin{array}{c}\text { Non- beneficiaries of lift } \\
\text { irrigation }\end{array}$} \\
\hline & Frequency & Percentage & Frequency & Percentage \\
\hline Age (Years) & 10 & 33.33 & 08 & 26.66 \\
\hline Young (<35) & 15 & 50.00 & 16 & 53.33 \\
\hline Middle (36-50) & 05 & 16.66 & 06 & 20.00 \\
\hline Old (>50) & & & & \\
\hline Education (Class) & 07 & 23.33 & 10 & 33.33 \\
\hline Illiterate & 11 & 36.66 & 12 & 40.00 \\
\hline Primary (1-7) & 10 & 33.33 & 04 & 13.33 \\
\hline Secondary school (8-10) & 00 & 00.00 & 04 & 13.33 \\
\hline HS school (11-12) & 02 & 06.00 & 00 & 00.00 \\
\hline College (>12) & 21 & 70.00 & 17 & 56.66 \\
\hline Occupation & 09 & 30.00 & 13 & 43.33 \\
\hline Agriculture & & & & \\
\hline Agriculture + Others & 04 & 13.33 & 02 & 06.66 \\
\hline Family size (No) & 24 & 80.00 & 26 & 86.66 \\
\hline Small family (<5) & 02 & 06.66 & 02 & 06.66 \\
\hline Middle family (5-8) & & & & \\
\hline Large family (>8) & 20 & 66.66 & 18 & 60.00 \\
\hline Land holding (ha) & 06 & 20.00 & 08 & 26.66 \\
\hline Small farmer (<2) & 04 & 13.33 & 04 & 13.33 \\
\hline Medium farmer (2-4) & & & & \\
\hline Large farmer (>4) & 04 &
\end{tabular}


Table.2 Pattern of land utilization by the beneficiary and no beneficiary (Area in ha)

\begin{tabular}{|c|c|c|c|c|c|c|}
\hline S. No. & $\begin{array}{l}\text { Size } \\
\text { Group }\end{array}$ & $\begin{array}{l}\text { Total } \\
\text { area }\end{array}$ & $\begin{array}{l}\text { Average size } \\
\text { of holding }\end{array}$ & $\begin{array}{c}\text { Net cultivated } \\
\text { area }\end{array}$ & $\begin{array}{c}\text { Irrigated } \\
\text { area (a) }\end{array}$ & $\begin{array}{l}\text { Number of } \\
\text { farmer (b) }\end{array}$ \\
\hline \multicolumn{7}{|c|}{ Beneficiary } \\
\hline 1 & Small & 319.968 & 2.0 & 319.968 & 319.968 & 400 \\
\hline 2 & Medium & 96 & 2.0 & 96 & 96 & 120 \\
\hline 3 & Large & 63.98 & 4.1 & 63.98 & 63.98 & 40 \\
\hline 4 & Overall & 480 & 2.14 & 480 & 480 & 560 \\
\hline \multicolumn{7}{|c|}{ Non- beneficiary } \\
\hline 1 & Small & 36 & 2.0 & 36 & 36 & 18 \\
\hline 2 & Medium & 32 & 4.0 & 32 & 32 & 08 \\
\hline 3 & Large & 20 & 5.0 & 20 & 20 & 04 \\
\hline 4 & Overall & 88 & 3.66 & 88 & 88 & 30 \\
\hline
\end{tabular}

Table.3 Asset positions of respondents of the study area

\begin{tabular}{|l|c|c|c|c|}
\hline \multirow{2}{*}{ Particulars } & \multicolumn{2}{c|}{ Beneficiaries } & \multicolumn{2}{c|}{ Non - beneficiaries } \\
\cline { 2 - 5 } & Average (Rs.) & Percentage & Average (Rs.) & Percentage \\
\hline Dwelling House & 72,600 & 30.88 & 56,883, & 24.61 \\
\hline Tractor & $1,11,666$ & 47.49 & $1,25,000$ & 54.13 \\
\hline Bullock cart & 5,525 & 02.35 & 5,200 & 02.25 \\
\hline Cattle shed & 15,714 & 06.68 & 12,500 & 05.41 \\
\hline Motor cycle & 19,600 & 08.34 & 21,250 & 09.20 \\
\hline Bicycle & 859 & 0.37 & 845 & 0.37 \\
\hline Iron plough & 2,100 & 0.89 & 7,350 & 1.02 \\
\hline Wooden plough & 375 & 0.16 & 375 & 0.16 \\
\hline Blade harrow & 475 & 0.20 & 462 & 0.20 \\
\hline Seed drill & 431 & 0.18 & 416 & 0.18 \\
\hline Spade & 100 & 0.04 & 87 & 0.04 \\
\hline Pickaxe & 135 & 0.06 & 120 & 0.05 \\
\hline Seed cum fertilizer drill & 5,545 & 2.36 & 5,500 & 02.38 \\
\hline Total & $\mathbf{2 , 3 5 , 1 2 5}$ & $\mathbf{1 0 0}$ & $\mathbf{2 , 3 5 , 9 8 8}$ & $\mathbf{1 0 0}$ \\
\hline
\end{tabular}

Table.4 Cropping pattern of the respondents in the study area

\begin{tabular}{|c|c|c|c|c|c|}
\hline \multirow[t]{2}{*}{ S. No. } & \multirow[t]{2}{*}{ Crops } & \multicolumn{2}{|c|}{ Beneficiaries } & \multicolumn{2}{|c|}{ Non- beneficiaries } \\
\hline & & Area (ha) & Percentage & Area (ha) & Percentage \\
\hline \multicolumn{6}{|l|}{ Kharif } \\
\hline & Maize & 93 & 38.00 & 5.80 & 32.95 \\
\hline & Tobacco & 101 & 41.50 & 7.36 & 41.68 \\
\hline & Bengalgram & 49 & 20.50 & 4.48 & 25.45 \\
\hline & Sub total & 243 & 100.00 & 17.6 & 100.00 \\
\hline \multicolumn{6}{|l|}{ Rabi } \\
\hline & Mirchi & 91 & 38.00 & 10.56 & 60.00 \\
\hline & Cotton & 146 & 62.00 & 7.04 & 40.00 \\
\hline & Sub total & 237 & 100.00 & 17.60 & 100.00 \\
\hline \multicolumn{2}{|c|}{ Net sown area } & 480 & & 35.2 & \\
\hline \multicolumn{2}{|c|}{ Gross cropped area } & 480 & & 35.2 & \\
\hline
\end{tabular}


Table.5 Cost of cultivation of different crops of the study area

\begin{tabular}{|c|c|c|c|c|c|c|}
\hline \multirow[t]{2}{*}{ S. No. } & \multirow[t]{2}{*}{ Operation } & \multicolumn{5}{|c|}{$\begin{array}{l}\text { Cost of cultivation of crops of beneficiaries of Nagulapadu } \\
\text { LIS (Rs./ha) }\end{array}$} \\
\hline & & Cotton & Tobacco & Chilli & Maize & $\begin{array}{l}\text { Bengal } \\
\text { gram }\end{array}$ \\
\hline 1 & Land lease (Rs/-) & 25000 & 25000 & 25000 & 25000 & 25000 \\
\hline 2 & Seed (Rs/-) & 6250 & 6250 & 16250 & 10000 & 3750 \\
\hline 3 & Ploughing (Rs/-) & 5000 & 5000 & 5000 & 5000 & 5000 \\
\hline 4 & Sowing (Rs/-) & 625 & 2000 & 4500 & 4500 & 1000 \\
\hline \multirow[t]{2}{*}{5} & Irrigation (No.s) & 4 & 4 & 6 & 4 & 2 \\
\hline & Irrigation charge (Rs/-) & 500 & 500 & 500 & 500 & 500 \\
\hline 6 & Fertilizer (Rs/-) & 8750 & 11250 & 21250 & 10000 & 3000 \\
\hline 7 & Feticides (Rs/-) & 5000 & 6250 & 17500 & 1250 & 3000 \\
\hline 8 & Weeding (Rs/-) & 3000 & 3750 & 3750 & 3750 & 1250 \\
\hline 9 & Harvesting (Rs/-) & 13750 & 20000 & 7000 & 4750 & 3125 \\
\hline 10 & Post harvesting (Rs/-) & 1000 & 1000 & 1000 & 1000 & 3500 \\
\hline 11 & Others (Rs/-) & 500 & 500 & 500 & 500 & 500 \\
\hline 12 & Crop period (Days) & 150 & 120 & 155 & 120 & 95 \\
\hline 13 & Base period (Days) & 45 & 30 & 145 & 110 & 65 \\
\hline 14 & Productivity (q/ha) & 37.5 & 47.5 & 75 & 100 & 25 \\
\hline 15 & $\begin{array}{l}\text { Cost of cultivation } \\
\text { (Rs/ha) }\end{array}$ & 68125 & 81500 & 97250 & 65250 & 49125 \\
\hline 16 & Market (Rs/q) & 3,500 & 4,000 & 4,500 & 900 & 2,400 \\
\hline \multicolumn{7}{|c|}{ Non-beneficiaries } \\
\hline 1 & Land lease (Rs/-) & 25000 & 25000 & 25000 & 25000 & 25000 \\
\hline 2 & Seed (Rs/-) & 6250 & 6250 & 16250 & 10000 & 3750 \\
\hline 3 & Ploughing (Rs/-) & 5000 & 5000 & 5000 & 5000 & 5000 \\
\hline 4 & Sowing (Rs/-) & 625 & 2000 & 4500 & 4500 & 1000 \\
\hline 5 & Irrigation (No.s) & 4 & 4 & 6 & 4 & 2 \\
\hline 6 & Irrigation charge (Rs/-) & 5000 & 7500 & 15000 & 10000 & 2000 \\
\hline 7 & Fertilizer (Rs/-) & 8750 & 11250 & 21250 & 10000 & 3000 \\
\hline 8 & Feticides (Rs/-) & 5000 & 6250 & 17,500 & 1250 & 3000 \\
\hline 9 & Weeding (Rs/-) & 3000 & 3750 & 3750 & 3750 & 1250 \\
\hline 10 & Harvesting (Rs/-) & 13750 & 20000 & 7000 & 4750 & 3125 \\
\hline 11 & Post harvesting (Rs/-) & 1000 & 1000 & 1000 & 1000 & 1000 \\
\hline 12 & Others (Rs/-) & 500 & 500 & 500 & 500 & 500 \\
\hline 13 & Crop period (Days) & 150 & 120 & 155 & 120 & 95 \\
\hline 14 & Base period (Days) & 45 & 30 & 145 & 110 & 65 \\
\hline 15 & Productivity (q/ha) & 32.5 & 35 & 60 & 85 & 35 \\
\hline 16 & Cost of cultivation (Rs/-) & 72625 & 88500 & 116750 & 74750 & 51625 \\
\hline 17 & Market value (Rs/q) & 3,500 & 4,000 & 4,500 & 900 & 2,400 \\
\hline
\end{tabular}


Table.6 Cost and returns structure of crops grown by the sample farmers (Rs. /ha)

\begin{tabular}{|c|c|c|c|c|c|c|c|c|c|}
\hline \multirow{2}{*}{$\begin{array}{l}\text { S. } \\
\text { no }\end{array}$} & \multirow[t]{2}{*}{ Crops } & \multicolumn{4}{|c|}{ Beneficiary } & \multicolumn{4}{|c|}{ Non-beneficiary } \\
\hline & & $\begin{array}{l}\text { Gross } \\
\text { Return }\end{array}$ & $\begin{array}{c}\text { Cost of } \\
\text { Cultivation }\end{array}$ & $\begin{array}{c}\text { Net } \\
\text { Returns }\end{array}$ & $\begin{array}{c}\text { Returns/ } \\
\text { rupee of } \\
\text { expenditure }\end{array}$ & $\begin{array}{l}\text { Gross } \\
\text { Return }\end{array}$ & $\begin{array}{c}\text { Cost of } \\
\text { Cultivation }\end{array}$ & $\begin{array}{c}\text { Net } \\
\text { Returns }\end{array}$ & $\begin{array}{l}\text { Returns/ } \\
\text { rupee of } \\
\text { expenditure }\end{array}$ \\
\hline 1 & Cotton & 131250 & 68125 & 63125 & 0.9 & 113000 & 77625 & 35375 & 0.45 \\
\hline 2 & Tobacco & 190000 & 81500 & 108500 & 1.3 & 140000 & 96000 & 44000 & 0.46 \\
\hline 3 & Chilli & 337500 & 102250 & 235250 & 2.3 & 270000 & 131750 & 138250 & 1.04 \\
\hline 4 & Maize & 90000 & 65250 & 63750 & 2.9 & 90000 & 84750 & 5250 & 0.06 \\
\hline 5 & $\begin{array}{l}\text { Bengal } \\
\text { gram }\end{array}$ & 60000 & 49125 & 10875 & 0.23 & 60000 & 51625 & 8375 & 0.16 \\
\hline
\end{tabular}

Table.7 Constraints faced by the beneficiary-farmers in percentage

\begin{tabular}{|c|l|c|c|c|c|c|c|}
\hline \multirow{2}{*}{ S. } & \multicolumn{1}{|c|}{ Particulars } & \multicolumn{2}{|c|}{ Severe } & \multicolumn{2}{c|}{ Medium } & \multicolumn{2}{c|}{ No problem } \\
\hline No. & & No & \% & No & \% & No & $\%$ \\
\hline 1 & Availability of water & $\mathbf{0 0}$ & $\mathbf{0 0}$ & $\mathbf{0 0}$ & $\mathbf{0 0}$ & $\mathbf{3 0}$ & $\mathbf{1 0 0}$ \\
\hline 2 & Co-operation of APSIDC staff & $\mathbf{0 0}$ & $\mathbf{0 0}$ & $\mathbf{0 7}$ & $\mathbf{2 3}$ & $\mathbf{2 3}$ & $\mathbf{7 7}$ \\
\hline 3 & Water charges & $\mathbf{0 0}$ & $\mathbf{0 0}$ & $\mathbf{0 0}$ & $\mathbf{0 0}$ & $\mathbf{3 0}$ & $\mathbf{1 0 0}$ \\
\hline 4 & Electricity Problems & $\mathbf{0 0}$ & $\mathbf{0 0}$ & $\mathbf{1 0}$ & $\mathbf{3 3}$ & $\mathbf{2 0}$ & $\mathbf{6 7}$ \\
\hline 5 & Suitability of land & $\mathbf{0 3}$ & $\mathbf{1 0}$ & $\mathbf{0 4}$ & $\mathbf{1 3}$ & $\mathbf{2 3}$ & $\mathbf{7 7}$ \\
\hline 6 & Suitability of Crops & $\mathbf{0 2}$ & $\mathbf{0 7}$ & $\mathbf{0 8}$ & $\mathbf{2 6}$ & $\mathbf{2 0}$ & $\mathbf{6 6}$ \\
\hline 7 & Soil Degradation $($ area) & $\mathbf{0 4}$ & $\mathbf{1 3}$ & $\mathbf{1 1}$ & $\mathbf{3 3}$ & $\mathbf{1 5}$ & $\mathbf{5 0}$ \\
\hline $\mathbf{8}$ & Availability of farm inputs & $\mathbf{0 0}$ & $\mathbf{0 0}$ & $\mathbf{0 0}$ & $\mathbf{0 0}$ & $\mathbf{3 0}$ & $\mathbf{1 0 0}$ \\
\hline
\end{tabular}

No significant difference was noticed in the value of assets across beneficiary and nonbeneficiary categories of farmers. The respondent's asset positions, analyzed in this study to fulfill the third objective of the research are presented in Table 3 .

The beneficiaries and non-beneficiaries cropping pattern in the study area was presented in Table 4. Similarly the cost of cultivation of different crops of both beneficiaries and non-beneficiaries in the study area was presented in Table 5.

The cost of cultivation of different crops of both beneficiaries and non- beneficiaries in the study area was studied by considering the investment incurred for all operation, were carried in the field right from selection of land on basis to the post operation level per hectare. During the study period it was observed that chilli was cultivated with highest amount with expenditure for beneficiary respondents Rs.116750 per hectare and followed by tobacco, maize, cotton and Bengal gram, Rs.88500, Rs.74750, Rs.72625, and Rs.49125 respectively for nonbeneficiaries Rs.131750, Rs.96000, Rs.84750, Rs. 77625 and Rs. 51625 respectively.

It was observed that among the all operations land lease was the major constituent with an amount of average Rs.25000 per hectare per year. In the study area about 95 per cent of the farmers were tenant farmers only. Further the cost of seed and cost of harvesting could be more in both respondents. Where as in the case of non-beneficiary farmers the irrigation 
charges were more about Rs. 8000 per hectare per year, even then the irrigation to the crops could be not effective due to power supply, pumps, motors and man power. Maize was the most profitable crop the net returns were observed for beneficiaries as Rs. 63750 per hectare per year and also the returns on rupee expenditure was Rs. 2.9 and followed by chilli Rs. 2.3, tobacco Rs. 1.3, cotton Rs. 0.9 and Bengal gram Rs. 0.23 respectively. Where as in the case of non-beneficiaries chilli was the most beneficial crop with a net returns of Rs.138250 per year per hectare and returns on rupee expenditure was Rs. 1.04 and followed by tobacco Rs. 0.46 , cotton Rs. 0.45 Bengal gram, Rs. 0.22 and maize, Rs. 0.06 respectively.

All the respondents farmers (100\%) opinioned that availability of the water in drain, water charges and availability of farm inputs were no problem since drain flows were continuous and excess than requirement. It was informed by all the respondents that the water charges were very affordable Rs.500 hectare per year. The Andhra Pradesh State Irrigation Development Corporation, Guntur, staff availability problem was observed medium severity $(23 \%)$. During the study period the electricity problem was medium severity due to $(30 \%)$ sudden interruptions in supply on suitability of land for irrigation was problem of medium severity.

It was concluded that chilli was cultivated with highest amount with an expenditure for beneficiary respondents Rs.116750 per hectare and followed by tobacco, maize, cotton and Bengal gram, Rs. 88500, Rs. 74750 , Rs. 72625 and Rs. 49125 respectively for non-beneficiaries Rs. 131750, Rs. 96000, Rs. 84750, Rs. 77625 and Rs. 49125 respectively.

It was observed that among the all operations land lease was the major constituent with an amount of average Rs. 25000 per hectare per year. In the study area about 95 per cent of the farmers were tenant farmers only.

It was found that Maize was the most profitable crop and the net returns were observed for beneficiaries as Rs. 63750 per hectare per year and also the returns on rupee expenditure was Rs.2.9 and followed by Chilli Rs.2.3, Tobacco Rs. 1.3, Cotton Rs. 0.9 and Bengal gram Rs. 0.23 respectively (Table $6)$.

In the case of non-beneficiaries chilli was the most beneficial crop with a net returns of Rs.138250 per year per hectare and returns on rupee expenditure was Rs. 1.04 and followed by tobacco Rs. 0.46 , cotton Rs. 0.45 , Bengal gram Rs. 0.22/- and maize Rs.0.06 respectively.

In both beneficiary and non-beneficiary category, the small farmers dominated in numbers. 60-67 per cent of farmers in both the categories were small. Medium farmers were the next important component in both the categories. While beneficiary category had about 20 per cent medium farmers, nonbeneficiary had 26.66 per cent of them.

\section{References}

Ahmed, S., Krishnaiah, 1998, changing gender roles in irrigation management, the case study of Sadguru's Lift Irrigation Co- operatives, Working paper, Institute of Rural Management, Anand. 120, $39 \mathrm{pp}$.

Anonymous, 1995, Annual Report on lift irrigation schemes. 1995. National Bank for Agriculture and Rural Development. Evaluation Study Series Regional Office Bombay, 45: 129.

Inamdar, P. P., Pawar, J. R., and Sale, D. L. 1996, Economic analysis of biwall lift irrigation unit for irrigating sugarcane 
crop in Maharashtra. A Report of Bharatiya Sugars Limited.
Utter Pradesh, Report of Indian Institute of Management, Ahmedbad, Gujarath.

Kolvalli, S., Gopalnaik, and Kalrao, 1993, Ground water Utilization in Eastern

\section{How to cite this article:}

Rama Rao, A. and Raghu Babu, M. 2018. Study on Socio Economic Aspects of the Farmers under Lift Irrigation Schemes on Nallamada Drain in Krishna Western Delta. Int.J.Curr.Microbiol.App.Sci. 7(10): 2085-2093. doi: https://doi.org/10.20546/ijcmas.2018.710.240 